\title{
WILL LEGAL EDUCATION REMAIN AFFORDABLE, BY WHOM, AND HOW?
}

\author{
JOHN R. KRAMER*
}

Law schools for the last twenty years have been testing the elasticity of demand for their product. As tuition has increased each year, outpacing even the rate of inflation, law schools have been pressing toward the point where significant numbers of college graduates may decide that it makes good economic sense to seek less expensive forms of graduate education or forgo additional credentials altogether.

Research to date has yielded no firm answer to the question of how elastic the demand for legal education is. Superficial evidence, however, suggests that demand has proven amazingly inelastic with reference to price. First-year enrollment has increased from 20,776 in 135 law schools in the 1963-64 academic year to 40,195 in 175 schools in 1986$87,{ }^{1}$ while tuitions have multiplied by factors as large as nine. Harvard Law School, for example, increased its tuition fron $\$ 1250 \mathrm{~m} 1961-62^{2}$ to $\$ 11,135$ in $1986-87,{ }^{3}$ while tuition has reached $\$ 12,484$ at other private schools. ${ }^{4}$

This apparent inelasticity is of course good news to administrators who have budgets that are heavily tuition-dependent. A more careful analysis, however, reveals ample reason for serious concern. The seats may be full in most law schools today. They may remain full tomorrow. They may even remain full until the year 2000 or beyond. But those seats may be filled almost exclusively by the sons and daughters of rich and upper-middle class white families and a handful of black and brown students from relatively impoverished backgrounds who receive substantial grants. Moreover, the seats may be filled in name only after the first year, with even the sons and daughters of the well-to-do working twenty hours a week in local law offices during the semester and forty hours a week during their summer "vacations." Finally, the seats may be filled with many more students who, as they become lawyers, do so with the

* Dean and Professor of Law, Tulane Law School

1. A Preliminary Review of Legal Education in the United States: Fall 1986, 1987 A.B.A. SEC. LEGAL EDUC. \& ADMISSIONS TO B. 178 [hereinafter 1986 REPORT].

2. HaRvard Univ., Official Register of HaRvard University-The LaW SchOOL Catalogue for 1961-1962, at 94 (1961).

3. K. Grove, Preliminary Data on Law School Tuition (Dec. 3, 1986) (Consultant's Memorandum C8687-48 to the Members of the Section of Legal Education and Admissions to the Bar).

4. Id. 
single-minded objective of milking the profession for all it is worth in order to be able to pay retrospectively for their legal education.

These trends are all "mays" and "mights," however, not "musts" and "shoulds." Their existence and persistence for the next thirteen years and beyond will depend on several factors: the costs, in terms of time and money, of acquiring a legal education; the expected returns, both economic and noneconomic, of investing that time and money; the availability of means to finance those costs and their side effects; and the viability of solutions to the problems created by those costs.

Existing programs and opportunities, furthermore, may minimize the fiscal harm to both law schools and their students and enable both groups to muddle through to the year 2000 despite ever-moreasing tuition. Nonetheless, the intellectual intensity of legal education, the socioeconomic makeup of the profession, and the incentives for lawyers to aid others at the expense of their own pocketbooks inevitably will suffer.

This article will examine the increasing cost of legal education and assess its inplications for both students and administrators. Part I analyzes the costs of attending law school and shows that these costs have outpaced inflation and are likely to continue to do so. ${ }^{5}$ Part II discusses the economic return froin legal education and demonstrates that the investment, notwithstanding inflation, provides a high rate of return. ${ }^{6}$ Part III discusses how a fundamental change in a basic assumption of professional education financing - shifting the burden froin parent to studenthas spawned a debt-driven financing regime. ${ }^{7}$ Part IV considers certain proposals for change, but ultimately rejects then because they appear to offer little or no rehef to students. ${ }^{8}$

\section{The Escalating Price Tag}

The escalating cost of general undergraduate education has recently sparked public concern. Speaking at Cathohic University in Washington in nid-Noveniber of 1986, Secretary of Education Williain Bennett called for "college cost containnient" and pointed out that "[b]etween 1975 and 1986, average college costs rose 150 percent: from $\$ 1,972$ to $\$ 4,917$. That's thirty-six percent faster than inflation . . . [and] twentyfive percent faster than inedian family income."

5. See infra notes 9-33 and accompanying text.

6. See infra notes $34-41$ and accompanying text.

7. See infra notes $42-128$ and accompanying text.

8. See infra notes $129-41$ and accompanying text.

9. Text of Secretary Bennett's Speech on College Costs and U.S. Student Aid, Chronicle of Higher Educ., Nov. 26, 1986, at 20, col. 2. 
While college costs have climbed rapidly, law school costs have leaped. The real cost of attending a law school cannot be accurately measured by simple referencc either to tuition charges or to what governinental programs deem to be the augmented "cost of attendance": tuition, fees, room and board, books, supphes, transportation, and iniscellaneous personal expenses. The real costs confronted by a prospective applicant include not only those items, but also the economic opportunity cost of not working for three years. ${ }^{10}$

\section{A. Tuition}

The latest American Elar Association surveys of law school tuitions $^{11}$ uses a 1974-75 baseline to compare the average and inedian tuitions in 1986-87 for resident students in public schools, nonresident students in public schools for 1985-86, and all students in private schools for 1986-87:

\section{$\underline{\text { Public Scliools (Resident Students) }}$}

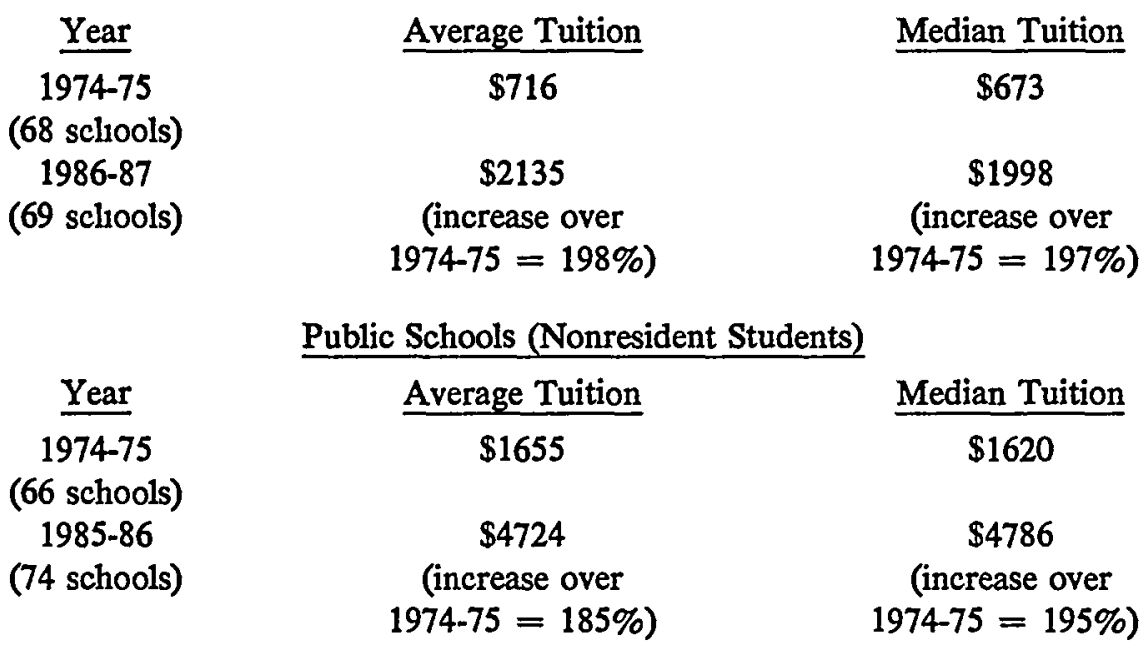

10. Because room and board and some personal expenses are necessary whether one goes to law school or directly to work, living expenses perhaps ought not be included in the calculations. Outlays for books and supplies are a function of law school attendance. Still, any student contemplating going to law school has to take a basic living expense budget into account. Even if that budget concerns expenses that have nothing specifically to do with going to law school, it merges in the minds of potential students with the barrier of tuition.

11. K. Grove, Tuition Over the Past Ten Years: 1976-1985 (July 28, 1986) (Consultant's Memorandum QS8586-53 to the Deans of ABA-Approved Law Schools); see also K. Grove, supra note 3. The 1974-75 figures are in J. White, Increase in Law School Tuition Since 1974, Table F-2 (Mar. 19, 1984) (Memorandum QS8384-42 to the Deans of ABA-Approved Law Schools). The calculations that follow in the text were all derived from the data contained in these documents. 


\begin{tabular}{ccc} 
& Private Schools (All Students) & \\
\cline { 2 - 3 }$\frac{\text { Year }}{1974-75}$ & $\frac{\text { Average Tuition }}{\$ 2305}$ & Median Tuition \\
$(88$ schools) & $\$ 8286$ & $\$ 2350$ \\
$1986-87$ & $($ increase over & $\$ 8042$ \\
$(89$ schools) & $1974-75=259 \%)$ & $($ increase over \\
& & $1974-75=242 \%)$
\end{tabular}

The increases in tuition range from a low of $185 \%$ to a high of 259\%. During the saine period-1974 to 1986-the Consumer Price Index rose shightly over $120 \%, 12$ the Service Sector Consumer Price Index rose approximately $150 \%, 13$ and the Higher Education Price Index, which reflects prices paid by colleges and universities, rose at least $120 \% .{ }^{14}$ Total charges for an undergraduate education at the average private university increased by $199 \%$ between 1973 and $1986,{ }^{15}$ an increase appreeiably lower than the increase in average tuition at private law schools.

Law school tuition increases, particularly at private schools, have outpaced all other indexes over the twelve-year period, reflecting the changing nature of legal education. Reduced student-faculty ratios, ${ }^{16}$ coniputerization, expanded hibraries, ${ }^{17}$ and increased law school scholarships have all contributed to rising tuition. ${ }^{18}$ Faculty salaries, meanwhile, rose only $127 \%$ during the same period. ${ }^{19}$

12. The Consumer Price Index for all items rose from 147.7 in 1974 to 311.1 in 1984 , an increase of $111 \%$ to which must be added inflation of approximately $6 \%$ from 1984 to 1986. STATISTICAL ABSTRACT OF THE UNITED STATES 1986, Table 795, at 477.

13. Id.

14. Id. Table 264, at 155. The index stood at 153 in 1974 and 325 in 1984.

15. Hartle, The Rising Cost of College: The Conventional Wisdom is More Complicated Than You Think, 67 EDUC. REc. (1986) (forthcoming).

16. There were 4881 full-time teachers and $118,700 \mathrm{~J}$.D. candidates in $1985-86$, see A Review of Legal Education in the United States: Fall 1985, 1986 A.B.A. SEc. LEGAL EDUC. \& ADMISSIONS To B. 66 , and 3584 teachers and 105,708 students in 1974-75. Figures for 1986-87 are not yet available. The resulting student-faculty ratio declined from 29.5-to-1 to 24.3-to-1, or by $17.5 \%$.

17. In 1974-75, the median volume size of ABA-approved law school libraries was 92,219. Telephone interview with Kathleen S. Grove, Assistant to the Consultant on Legal Education to the ABA (Jan. 13, 1987). In 1985-86, it was 197,922. K. Grove, Law Library Data (July 28, 1986) (Consultant's Memorandum QS8586-60 to the Deans of ABA-Approved Law Schools). That is an $115 \%$ increase.

18. Tuition-related law school scholarships amounted to $\$ 13,165,000$ in $1978-79$. J. White, Overview of Scholarship Programs at 150 Private and Public Law Schools 1979-80, Table J-1 (Jan. 29, 1980) (Consultant's Memorandum QS8586-60 to the Deans of ABA-Approved Law Schools), and $\$ 54,762,420$ in 1986-87. K. Grove, Overview of Scholarship Programs for 174 ABA-Approved Law Schools, Table J-2 (Mar. 17, 1987) (Consultant's Memorandum QS8687-37 to the Deans of ABA-Approved Law Schools). That is a $316 \%$ increase.

19. Median salaries were $\$ 23,350$ in $1974-75$ and $\$ 50,100$ in $1985-86$. K. Grove, Faculty Purchasing Power Since 1970 (July 25, 1986) (Consultant's Memorandum QS8586-51 to the Deans 
The implications of ever-inereasing tuition are staggering. The average annual increase for in-stiate students at state umversity law schools over the twelve years was $9.6 \%$, while at private schools the increase was $11.3 \% .{ }^{20}$ Were the saine average increases to occur through 2000-01, the average tuition for an in-state resident at a public law scliool would be $\$ 7700$ and the average tuition at a private law school would be $\$ 37,100$.

Even if increases were held to $5 \%$ or $7 \%$ over the same period, the results for 2000-01 would still be high:

(a) Average for

Percentage

Increase

1974-1986

(Public: $9.6 \%$

Private: $11.3 \%$ )

(b) $5 \%$

(c) $7 \%$
Average Public School Tuition (Resident) in 2000-01

7705

4227

5505
Average Private School Tuition in 2000-01

These tuition figures only represent average tuitions. Because people who are five feet tall can drown in a river that has an average depth of three feet when they encounter a six-foot depression, it is advisable to look at the extremes. In 1986-87, forty-five law schools (more than $25 \%$ of all schools) had tuitions in excess of $\$ 8000$, with five exceeding $\$ 12,000$ and twelve between $\$ 10,000$ and $\$ 12,000.21$ Should these price tags increase in the next fourteen years at a rate comparable to that during the preceding twelve, tuition levels at some schools could approach $\$ 60,000$ by the year 2000 .

The impact that such tuition increases have had and will have on a family's ability to pay for tuition out of current income is significant. Average law school tuition as a percentage of median family income moved from $5.2 \%$ in 1974-75 to $6.8 \%$ in 1984-85 for public schools; it moved from $16.8 \%$ to $26.1 \%$ for private schools. ${ }^{22}$ The significance of the relationship between law school tuition and median family income in recent years is somewhat tempered if one considers the median income

of ABA-Approved Law Schools). By 1986-87, the national median of base salaries of full-time faculty had risen to $\$ 53,080$. K. Grove, Median Base Salaries (Nov. 17, 1986) (Meriorandum QS8687-3 to the Deans of ABA-Approved Law Schools).

20. For the source of the underlying data, see $K$. Grove, supra note $3 ; \mathrm{K}$. Grove, supra note 11 ; and J. White, supra note 11.

21. K. Grove, supra note 3.

22. Statistical AbStract of the United States 1986, Table 752, at 450. In March 1975, median family income was $\$ 26,433$. In 1984 , average law school tuition was $\$ 1803$ for public schools (resident) and $\$ 6898$ for private schools. K. Grove, supra note 3. 
only of those families with children in college instead of the median imcoine of all families. ${ }^{23}$ Families with children in college had a median income of $\$ 38,500$ in 1985,24 of which average private law school tuition in 1985 would have consumed only $19.5 \%$. Regardless of which income is used as a reference point, a majority of families would have to forgo a significant portion of their annual income to pay a child's legal tuition.

\section{B. Other Costs of Attendance.}

The continued affordability of legal education grows more doubtful when room, board, and other expenses are considered. Although no solid data on average or median law student hiving expenses exist, the school-by-school estimates of total hiving expenses for 1986-87 suggest a median outlay in the $\$ 6000$ to $\$ 6500$ range per student for a single student not hiving at home for the nine months of law school. ${ }^{25}$ More than fifteen schools report, however, that such expenses exceeded $\$ 9000 .{ }^{26}$

These figures, which are developed by financial aid personnel, tend to be derived from the Bureau of Labor Statistics' low and moderate expense budgets for nine months for persons in the twenty- to thirty-fiveyear-old age group. ${ }^{27}$ The low expense budget figures range from $\$ 6004$ in Honolulu to $\$ 4241$ in Dallas, and the moderate budget figures range from $\$ 8941$ in Honolulu to $\$ 6315$ in Dallas. ${ }^{28}$

There is no basis for projecting the Consumer Price Index to 200001 , but an increase of at least $100 \%$ seems probable, given the experience over the past fourteen years and assuming inflation averages between $4 \%$ and $5 \%$ annually. That $100 \%$ increase would place the average total cost of attendance at a private school in 2000-01 on a continuum from $\$ 29,000$ to $\$ 55,000$, with the public schools costing from $\$ 16,700$ to $\$ 20,200$ per year.

\section{Lost Earnings.}

The lost economic opportunity of full-time eniployment for three years is, perhaps, as large a deterrent to applying to law school as the

23. See Hartle, supra note 15 , at 3-4. According to Hartle, median family income between 1973 and 1985 went up $126 \%$ for all families, but $144 \%$ for families with a dependent child in college.

24. Id.

25. K. Grove, Student Living Expenses for Single Student Living Away From Home (Dec. 3, 1986) (unpublished table).

26. Id.

27. See, eg., Bureau of Labor Statistics, U.S. Dep'T of Labor, Three Standards of Living for an Urban Family of Four Persons (1967) (Bull. No. 1570-5).

28. Graduate \& Professional Student Financial aid Service, Bls living ExPENSES BUDGETS AWARD YEAR 1987-88, at 12-14 (1986) [hereinafter LIVING EXPENSES 1987-88]. 
expected cash outlays. Data on the starting salaries for graduating college seniors with bachelor degrees in the hiberal arts are difficult to collect, but the College Placement Council places the average starting salary at approximately $\$ 18,000$ for 1985 graduates. ${ }^{29}$ Assuming a 3\% raise in each of the years commencing in 1987, the graduate would earn approximately $\$ 59,150$-less $\$ 4440$ for social security and $\$ 8880$ for mcome taxes. ${ }^{30}$

Not all of this $\$ 45,800$, of course, would necessarily have to be forgone to attend law school. First-year students should not and usually do not work except on internal law school chores subsidized by work-study. But a majority of second- and third-year students can obtain jobs with law firms. These jobs can pay up to $\$ 10,800$ for work during the two academic years (six to twelve dollars an hour, twenty hours a week, over a thirty week period), from $\$ 2880$ to $\$ 4800$ for twelve weeks in the summer after the first year, and froin $\$ 7000$ to $\$ 15,400$ during the suminer of the second year.

The total $\mathrm{m}$-school earning possibilities, therefore, range froin $\$ 17,100$ to $\$ 31,000$ - only $\$ 28,150$ to $\$ 42,100$ less than that which would have been earned had the student not attended law school. Reduced income and social security taxes further diminish the gap by approximately $\$ 7300$ to slightly less than $\$ 21,000.31$

The income forgone for one year (approximately $\$ 19,150$ in 1987) is so modest after subtracting $\$ 4240$ for federal and state income and social security taxes, a sum for the added expenses of working (such as transportation and clothing expenses), and $\$ 9462$ for a moderate twelvemonth consumption budget ${ }^{32}$ that it does not make economic sense for

29. Four Years in College: What You Pay, What You Get, U.S. News \& WorLd ReP., Nov. 25,1985 , at 60 . Social science majors were offered an average starting salary of $\$ 18,540$, while humanities majors were offered \$17,532. The annual College Placement Council report has been discontinued because of budgetary reasions. See Greene, Job Outlook for 1987's Graduating Seniors: Level Hiring, Lagging Pay, and Drug Tests, Chronicle of Higher Educ., Jan. 7, 1987, at 33, col. 2. The American Federation of Teachers Salary Report places 1985 starting salaries for liberal arts majors at \$18,828. Education Life, N.Y. Times, Apr. 12, 1987, § 12, at 19, col. 1.

30. Social security tax in this and all subsequent calculations is figured at $7.15 \%$ for 1987 , $7.51 \%$ for 1988 and 1989 , and $7.65 \%$ for 1990 . Federal taxes are computed at the rates under the 1986 law for single persons ( $11 \%$ from $\$ 0$ to $\$ 1800$ in $1987,15 \%$ from $\$ 1800$ to $\$ 16,800$, and $28 \%$ up to $\$ 27,000 ; 15 \%$ for the first $\$ 17,850$ in 1988 and beyond and $28 \%$ above that up to $\$ 43,150$ ). The computations account for the appropriate individual personal exemption ( $\$ 1900$ for $1987, \$ 1950$ for $1988, \$ 2000$ for 1989 ) and the standard deduction for single persons $(\$ 2540$ for 1987 and $\$ 3000$ for 1988 and beyond).

31. The difference would, of course, be further reduced were clerking wages during the school year and the summer to keep pace with associates' starting salaries. The trade-off between taking a job immediately upon graduating from college and the economic benefits attendant upon that degree, furthermore, must also be considered.

32. LIVING EXPENSES 1987-88, supra note 28. 
one to stay out of school to earn one's tuition. The sum actually saved after twelve months of work would not substantially exceed $\$ 5000$ and would probably be much less. That amount would not cover the cost of average private school tuition, let alone the total cost of attendance. At the same time, the worker would have exchanged paying tuition in 1987 88 for paying tuition in $1990-91$ (at a private law school, nearly $\$ 3500$ more) and would have sacrificed one year of a lawyer's salary in the mid$\$ 30,000$ range. At present, a person cannot afford not to go to law school. To do so would ultimately cost $\$ 15,000$ or more.

Although the lost economic opportunity of attending law school is significant when viewed without reference to the economic opportumity available to attorneys, it is not likely to grow over the next fourteen years. If beginning salaries for hiberal arts graduates follow the past pattern and increase at a slower rate than the salaries available to law school students, ${ }^{33}$ the gap between the potential earnings of a full-time working liberal arts graduate and a law student should not widen.

\section{The True Burden of Attending Law School.}

A college graduate thinking about going to law school in the fall of 1987 would have to assess the potential cost by cumulating, for a threeyear period, the following: average tuition ( $\$ 7070$ to $\$ 7720$ for public law schools, depending on the rate of tuition increase; $\$ 27,430$ to $\$ 30,910$ for private law schools, with some as high as $\$ 46,260$ ), the median cost of living for three nine-month periods on a modest budget $(\$ 20,000)$, and the forgone economic opportunity $(\$ 21,000$ to $\$ 35,000)$. That calculation would yield a total cost that could be as low as $\$ 48,070$ for a student attending a public law school and working to the fullest possible extent at the best of wages, but as high as $\$ 101,260$ for a student attending the most expensive of private schools and not working.

The range is instructive. In the 1970's, a chiche was that the second most sizeable financial investment an individual would ever make, after buying a home, would be the purchase of a car. By the early 1980's, however, the cost of graduate education, especially legal and medical education, had easily displaced the cost of a car, except perhaps for a luxury car such as a Mercedes-Benz. By the late 1980's, even the MercedesBenz has succumbed and only a Rolls-Royce stands ahead of legal education (and, of course, medical education) as the most expensive capital asset other than a home that individuals can buy.

33. The average starting salaries for graduates with bachelor's degrees will be up only $2.1 \%$ from 1986 to 1987. Greene, supra note 29. 
By the year 2000 , a prospective law student might find a two-bedroom condominium cheap by comparison (outside of New York and Los Angeles). Public school tuitions for a student graduating in 2003 might total between $\$ 13,340$ and $\$ 25,400$, and private school tuitions between $\$ 51,720$ and $\$ 124,320$. Expenses may be as much as $\$ 39,000$, and forgone economic opportunity may be $\$ 40,000$. The bottom and peak totals would be $\$ 92,340$ and $\$ 203,320$, respectively, although a median range of $\$ 110,000$ to $\$ 170,000$ seems most hikely.

\section{Is LA.W SchOOL WORTH IT?}

Who would want to invest in a product as expensive as legal education? By virtue of the act of applying, current law students have clearly determined that there must be a favorable benefit-cost ratio. Without calculating the precise nature of the pecuniary benefits, they realize that enrolling in law school will be worth more than froin $\$ 16,025$ to $\$ 33,750$ a year in costs.

Attempts to test that response, which was shared by more than 61,000 applicants in the academic year 1985-86, suggest that the intuition is accurate. Although data on the earnings of attorrieys tend to be unreliable because of voluntary reporting and incomplete surveys, the information available for 1985 indicates that the median starting salary for attorneys entering private practice was between $\$ 31,200$ and $\$ 32,500$, and $\$ 33,200$ for attorneys going into corporate law departments. ${ }^{34}$ By 1986 , the inedian starting salary had gone up almost $11 \%$ to $\$ 36,000$ (compared to a median income of $\$ 45,605$ for all law firm associat $\epsilon s$ ). ${ }^{35}$ Federal judicial clerks received $\$ 26,381$, and public defenders, assistant district attorneys, assistant city or state attorneys, and some public interest attorneys received salaries in the middle to upper end of the twenty to thirty thousand dollar range. ${ }^{36}$

Moreover, applicants cannot ignore the fact that in 1986, Cravath, Swaine \& Moore increased its annual starting salary to $\$ 65,000$. That figure has been ineradicably planted im the minds of many applicants who believe that three years of excellent scholastic performance will qualify them to grab that particular ring.

At $\$ 36,000$, in any event, the median starting salary of the twothirds of graduating law students who enter private practice is approxi-

34. See Salary Gap Is Closing, A.B.A. J., Dec. 1, 1986, at 26 (survey conducted by Cantor \& Co., Philadelphia, $\mathrm{Pa}$.).

35. See 1985 Associate Pay Increases Exceeded Partners' Raises, D.C.B.J., Sept.-Oct. 1986, at 21 (survey conducted by Altman \& Weil, Ardmore, $\mathrm{Pa}$.).

36. The Wages of Time, Student. LAw., Nov. 1986, at 27-31 (survey conducted by David J. White \& Assocs.). 
mately $\$ 17,000$ a year more than what a bachelor of arts degree holder earns. Even if the rate of salary increase for each job were to be the same, the gap would increase to $\$ 19,610$ by the time the apphicant graduated in 1990 and would be over $\$ 23,000$ within five years of graduation. Thus, a public law school applicant contemplating paying an average of $\$ 27,720$ to $\$ 28,840$ over three years for tuition and living expenses in addition to forgoing $\$ 35,000$ in lost wages could reasonably expect to recoup the $\$ 62,720$ investment through wage differentials over a threeyear period. A private law school applicant would have to wait somewhat longer to recover the investment, because $\$ 68,430$ (average tuition rising only 5\% annually with high in-school earnings) would take three and one-third years to recover. At the maximum, for the most expensive private schools, with no in-school work, $\$ 112,060$ could be recovered a little more than five years after beginning work in a law firm at the median starting salary. ${ }^{37}$

In addition, if the lyypothetical 1986 law school applicant achieved partnership, the gulf between the pedestrian annual salary increases of the B.A. holder and the imcome leap of the attorney would soon lead to annual income differentials greater than the entire original investment. Of course, the demand for attorneys vis-à-vis college graduates could diminish, thereby decreasing the earnings gap, but there is hittle evidence that such a development is likely.

These projections suggest that extra annual income produced by a legal career will produce a net rate of return on investment somewhere between $20 \%$ and $30 \%$. By contrast, people who have only an undergraduate degree can expect a net rate of return on investment between $7.5 \%$ and $21.4 \% .^{38}$ Clearly, attorneys can expect to exceed considerably the $\$ 640,000$ lifetime earnings differential that Secretary Bennett has said exists between the college degree holder and the individual with only a high school diploma. ${ }^{39}$ The investinent in legal education is undeniably greater, but so is the ultimate return.

A rate of return on investment between $20 \%$ and $30 \%$, particularly where the indications are strong that the rate would continue and accelerate for a period of twenty-five to thirty-five years after imitial recoupment, indicates that the applicants' intuition is right. The J.D. degree is a good investment.

37. None of these calculations accounts for the interest cost flowing from borrowing, but that cost is partially offset by the discounted present value of deferred payments.

38. See Senate Comm. on labor and human Resources, 99th Cong., 1st Sess., Reauthorization of the Higher Education Act 42-43 (Comm. Print 1985).

39. Text of Secretary Bennett's Speech on College Costs and U.S. Student Aid, Chronicle of Higher Educ., Nov. 26, 1986, at 22, col. 1. 
This insight is hardly novel. In 1953 at one of the first meetings of legal educators seriously to contemplate the problem of financing legal education, a similar analysis emerged as the basis for the claim that a loan program should be developed to underwrite legal education:

Education is a long range capital investment capable of returning high yields. The difference between the cost of a legal education and its value in terms of lifetime earnings is proportionately much greater than the returns ordinarily experienced on invested capital. The average annual earmings of lawyers exceed that of skilled industrial workers by almost $\$ 5,000$ per year. This greater annual return inakes legal education a sound investment. On most durable items that one can think of-automobiles, homes, farms, and businesses-Americans without ready cash buy on time. They do it without a second thought; it is a national habit. It is consistent with this national pattern of financing that legal education, where not otherwise available to a deserving student, be financed on a time basis. Unfortunately, taking approved law schools as a group, there is an absence of any adequate facilities to finance a legal education on time. 40

This analysis assumes that the desire to earn a J.D. is driven exclusively by the economic benefits of a legal education. Indeed, the fifteenyear trend away from doctorates to law degrees and the more recent minor trend away from law to mvestment banking ${ }^{41}$ indicates that the desire to become an attorney is often triggered by the desire to have the most remunerative career possible. Nonpecumary benefits, however, including better access to positions of power in society, greater job satisfaction and challenge, and higher social prestige certainly supplement that desire for greater earnings.

However distasteful it inay seem to legal educators and attorneys, one way to ensure a continuing pool of applicants to fill the approximately 40,000 seats available each year in first-year classes is to emphasize expected rates of return in addition to the other, more professionally acceptable values associated with the practice of law.

\section{How CAN the Costs Be Borne?}

Legal education is obviously a very worthwhile investment, but an investment that cannot be financed is an investment unmade. The traditional sources of cash for a student's legal education have been the student's family, the law school itself, the state, the federal government, private contributors, and the student's employer. The continued ability of these sources to bear the costs of legal education is examined below.

40. Loans for Law School Students, 5 J. Legal Educ. 312, 314 (1953).

41. See Vernon \& Zimmer, The Size and Quality of the Law School Applicant Pool: 1982-1986 and Bejond, 1987 DUKE L.J. 204. 
The two most important sources of support for the law student-the family and the federal government-will be considered first. Other, less obvious but nonetheless important sources-the law schools, the states, private contributors and employers-also will be discussed.

\section{A. The Family.}

For many years the basic assumption underlying the financing of higher education has been that parents would use savings and current earnings to pay for their child's education. This assumption becomes less valid once the child has graduated from college, however. Parents who have sacrificed to pay for a child's undergraduate education are increasingly less willing to pay for graduate school and more inclined to demand that their child cover some of the costs. ${ }^{42}$

The changing assumption about parental responsibility for financing education appears even more reasonable when one considers the number of students who have been out of college two or more years. The percentage of law school apphicants who are two years or more out of college now approaches $44 \%$, with $25 \%$ more than five years ont of college. Thus, students are much less able to turn to their parents for the money necessary to finance their legal education.

The Higher Education Amendments of $1986^{43}$ at last acknowledged the legitimacy of the student's nced for rehef. Under the 1986 amendments, graduate or professional students are recognized as per se independent of their parents for purposes of computing need for federal aid as of January 1987, provided they declare that they would not be claimed as tax dependents in the first calendar year for which the federal aid was awarded.44 Prior to 1987, no graduate student was considered independent if (1) the student had been a tax dependent in the calendar year prior to attending law school as well as the first calendar year of attendance, or (2) had received more than $\$ 750$ in parental support during that academic year, or (3) had hived with his or her parents for six weeks or more over the course of the year. ${ }^{45}$ If any one of those three factors obtained, the law student was viewed as dependent and the student's parents were expected to contribute to the student's law school education according to a complicated need analysis. The student was deemed to have that contribution available whether or not the parents ever actually gave it to the

\footnotetext{
42. A. Hauptman, Students in Graduate and Professional Education: What We KNOW AND NEED TO KNOW 55-56 (1986).

43. Pub. L. No. 99-498, 100 Stat. 1268 (1986).

44. Id. $\S 480(d)(2)(\mathrm{c}), 100$ Stat. at 1474.

45. 34 C.F.R. $\S 668.1$ (b) (1986).
} 
student. The traditional assumption of parental responsibility trumped economic reality.

As of 1987, parents of graduate students will no longer be under a formulaic mandate to contribute, except when the parents decide that a $\$ 1900$ tax exemption is more important than facilitating their child's access to as much as $\$ 7500$ in Guaranteed Student Loans and other loan and work-study benefits. As long as the exemption is not claimed, each professional student is presumed to bear the full burden of the costs of legal education.

Whetler or not actual parental contributions will decline as a result of this change is uncertain. Parents remain free to help their children attend law school, and such contributions would reduce the amount the students would otherwise have to obtain. Indeed, the Conference Report on the 1986 amendments contains a warning by the managers that "it is the intention of the conferees" that aid officers carefully evaluate students from high income families enrolled in high cost programs "to determine if a parental contribution is warranted." 46

The exact level of current parental contributions is not known, but lias been estimated to be at least $\$ 400$ million and perhaps as inucli as $\$ 500$ million-an average of $\$ 3500$ to $\$ 4000$ per student. ${ }^{47}$ This contribution level puts the family on par with the federal government with regard to the amount of funds provided students for their legal education. The reality, lowever, is that the average figure is irrelevant. Most students are given either more than $\$ 10,000$ or nothing at all. The legal transfer of funding responsibility from the generation of the parents to the generation of the students inay encourage soine parents to abandon a previously accepted responsibility. To the extent that the roles are reversed and students assurne the obligation to find money for legal education themselves, the traditional social contract governing education will liave been turned upside down. That cliange places a greater burden on the remaining sources of support for a student's legal education.

\section{B. The Federal Government.}

Witlout the intervention of federal government in the 1970's, legal education as we know it today would not exist. Law schools, wlich serve the needs of clients who are predoininantly corporations or wealthy individuals, are essentially socialized institutions. If public, they are dependent for their survival on the state that funds them (only Alaska, Ne-

46. H.R. Rep. No. 861, 99th Cong., 2d Sess. 416 (1986).

47. See Zimmer, Survival After the Boom: Managing Legal Education for Solvency and Productivity, 34 J. LEGAL EDUC. 437, 444-45 (1984). 
vada, and Rhode Island do not have publicly supported law scliools) as well as on federal loans. If private, they depend on the subsidized loan programs offered by the federal government.

This dependence on federal loans is relatively recent. The Guaranteed Student Loan (GSL) program was created in 1965; under the program, qualifying law students were entitled to as much as $\$ 1500$ in loans that were guaranteed by the United States and were interest free while the student was in school. The niaximum loan was later boosted to $\$ 2500^{48}$ and then to $\$ 5000$ in 1976.49 Law students did not begin to use GSLs to a significant extent until after 1978, when the Middle Income Student Support Act rennoved sone income eligibility limitations applicable to GSLs. ${ }^{\text {so }}$ By 1980-81, law students had $\$ 210$ million in GSLs$\$ 171.7$ million for students at private law school and \$38 million for students at public law schools, or $66 \%$ of private school and $78 \%$ of public scliool tuition in that year. ${ }^{51}$ The loan amounts were at their peak in 1985-86 at $\$ 307$ million. ${ }^{52}$ The percentage of tuition accounted for by loans reached $68.3 \%$ for private schools in $1981-82^{53}$ and has declined steadily to $39 \%$ in $1985-86 .{ }^{54}$ Public scliools had $119.4 \%$ of their tuition and fees loan-financed in 1981-8255 and $86 \%$ in 1985-86.56

Law students are, pound-for-pound, the most vigorous loan program users. They represent only slightly over $9 \%$ of all of the students enrolled part-time or full-time in graduate and professional education ${ }^{57}$ and less than $1 \%$ of all of the students involved in higher education, ${ }^{58}$ but they consumed 3.3\% of all GSL and PLUS loans awarded in 1985$86 . .^{59}$ Similarly, they obtained $3.5 \%$ or $\$ 29.4$ million of the $\$ 841$ million

48. Act of June 23, 1972, Pub. L. No. 92-318, 86 Stat. 261.

49. Act of Oct. 12, 1976, Pub. L. No. 94-428, 90 Stat. 2104.

50. Middle Income Student Assistance Act, Pub. L. No. 95-566, 92 Stat. 2402, 2402-04 (1978).

51. These figures are based on the assumption that the loans were applied solely to tuition and fees. J. White, Federally Guaranteed Student Loans as a Percentage of Law School Tuition and Fees, Table J1A (Feb. 26, 1982) (Consultant's Memorandum QS8182-6A to the Deans of ABAApproved Law Sclools).

52. The figure for private law schools was \$231.6 million in 1983-84, and the figure for public law schools was $\$ 92.5$ million in 1985-86. K. Grove, Federally Guaranteed Student Loans as a Percentage of Law School Tuition and Fees, Table J-1 (July 28, 1986) (Consultant's Memorandum QS8586-58 to the Deans of ABA-Approved Law Schools).

53. J. White, supra note 51 .

54. K. Grove, supra note 52.

55. J. White, supra note 51.

56. K. Grove, supra note 52.

57. A. HAUPTMANN, supra note 42 , at 2,4 .

58. Id.

59. These figures are based upon $\mathrm{K}$. Grover, supra note 52 and THE CollEGE BOARD, TRENDS IN STUDENT AID: 1980 to 1986, Table 1, at 6 (1986). 
in National Direct Student Loans given in 1985-86.60

Law student use of the loan programs is disproportionate because of the high cost of attending law school compared to other forms of higher education. In 1983-84, tuition at 400 graduate and professional schools exceeded $\$ 5000 .{ }^{61}$ Seventy-nine of these were law schools-exceeded only by 127 graduate arts and sciences programs and closely followed by seventy medical and sixty-five graduate business schools. Because a student's GSL eligibility depended on a relationship between that student's family's expected contribution and the cost of attending a particular school, high tuitions rendered the student eligible for larger loans.

1. The Higher Education Amendments Act of 1986. High tuition levels explam why law schools took the lead im the spring of 1984 in pressing the Secretary of Education to raise the $\$ 5000$ GSL loan ceiling for students enrolled in graduate and professional programs that entail exceptionally high costs of education. ${ }^{62}$ The Secretary declined to act in 1985. ${ }^{63}$ Accordingly, Congress undertook to raise the ceilings as part of the Higher Education Amendments Act of 1986.64

The crucial terms that make the loan programs more or less attractive to law students have been altered by the 1986 amendments in a manner almost invariably favorable to law students. Those terms and those changes are highlighted in the following table. The old terms are placed in parentheses after the changes. No parentheses imdicates that no change was made by the 1986 amendments.

60. These figures are based upon K. Grove, Loan Funds Other Than FGSLs at 164 ABAApproved Law Schools, Table J4 (Mar. 24, 1986) (Consultant's Memorandum QS8586-28 to the Deans of ABA-Approved Law Schools) and THE CollegE BOARD, supra note 59, at 6, Table 1.

61. Memorandum in Support of Petition to Raise Annual and Cumulative Loan Limits Under the Guaranteed Student Loan Progran for Professional and Graduate Students Pursuing Programs Requiring Exceptionally High Cost of Education 16, apps. A \& B, Table 1 (1984) (memorandum submitted to the Secretary of Education on behalf of the Association of American Law Schools).

62. Id.

63. Letter from Secretary Willian J. Bennett to Glenn S. Gerstell of Milbank, Tweed, Hadley \& McCloy (Mar. 12, 1985).

64. Pub. L. No. 99-498, $\S 428(b)(1)(A)(i i i), 100$ Stat. $1268,1370$. 
Guaranteed Student Loans

(GSL)

(1) Income Eligibility

Almost all law students will be independent and thus may qualify for full amount (Family Contribution Schedule took into account parents' adjusted gross imcome)-full financial need test (only if income over $\$ 30,000$ ).

(2) Annual loan maximum $\$ 7500$

(3) Cumulative inaximum $\$ 54,750$

$(\$ 15,000)$ which

includes undergraduate GSLs.

(4) Interest rate

After July 1, 1988, $8 \%$ for first four years, $10 \%$ for remainder; but if 91day Treasury bill rate plus $3.25 \%$ is less than $10 \%$, the difference is credited against principal balance ( $8 \%$ for any borrower postSeptember 13, 1983; $7 \%$ for any borrower prior to January 1, 1981; $9 \%$ for all other borrowers). rate plus $3.75 \%$ up to $12 \%$ maximum; but $14 \%$ if 91 -day Treasury bill rate exceeds $14 \%$ if refinanced with charge to borrower of up to $\$ 100$. Variable rate will lengthen/ shorten number of payments or monthly amount of payment.
Supplemental Loans

for Students (PLUS/

AAS)

$\$ 4000$

$(\$ 3000)$

Perkins Loans

National Direct

Student Loans

(NDSL)

No limitation.

Same as GSL, although eacli law scliool usually furtlier assesses relative need in order fairly to distribute its limited allotment, which will be affected by allotment freeze at the 1984-85 level for most schools (repeal of state allocation formula).

$\$ 5000$-but no law student gets that amount because of allotment limits.

$\$ 20,000$

$\$ 18,000$

$(\$ 12,000)$.

$(\$ 12,000)$ which

imcludes

undergraduate

NDSLs.

After July 1, 1987, 91-day Treasury bill $5 \%$ if loan after October 1, 1981. 
(5) In-school payment

None required.

Interest only due 60

None required.

days after loan, but principal and interest inay be deferred and capitalized.

(6) Grace period prior to repayment

Six months after graduation.

Upon graduation.
Nime months after graduation (six).

(7) Out-of-school payment duration

Ten years maximum for each loan, subject to consolidation of all such loans if they exceed a total of $\$ 5000$ at a weighted average interest rate, but in no event less than $9 \%$, with term of 12 years for loans from $\$ 5000$ to $\$ 9999 ; 15$ years for loans froin $\$ 10,000$ to $\$ 19,999 ; 20$ years for loans from $\$ 20,000$ to $\$ 44,999$; and 25 years for loans $\$ 45,000$ or more. Graduated/income sensitive repayment schedules up to lender (no consolidation available after November 1, 1983).

(8) Minimum repayment $\$ 600$ a year. $\$ 600$ a year. $\$ 30$ a month.

(9) Origination fee

Five pereent $-\$ 375$ maximum (\$250).

None.

None.

(10) Deferment

Less than full-time students; whenever unemployment for 24 months (once, if unemployed for twelve months); parental leave for up to six months; preschool mothers entering work force and earning less than $\$ 1$ over minimum wage.

(11) Insurance premium Limited to $3 \%$ of loan (variable, but up $1 \%$ per years in school plus eleven months).

\section{Same as GSL} (variable, but up to $1 \%$ per year during lesser of life of loan or 60 months).
Parental leave and preschool mothers as in GSL.

Not applicable. 
When coupled with aid from one of the other sources of funding analyzed here, the inodified federal loan programs (GSL and SLS) enable nearly every admitted applicant to attend law school in 1987. Some of the major problems that undermined the utility of the programs have been resolved either by economic circumstances, congressionally mandated alteration, or the intervention of the Law School Admission Council and its Law Student Assured Access Program (LSAAP). These problems included eligibility, the availability of capital, the adequacy of the dehivery system, the existence of required interest payments while in school, and, perhaps most significant of all, the dollar value of the loans. Some minor problems continue, particularly the persistence of the $5 \%$ origination fee, ${ }^{65}$ but the cost savings of $\$ 400$ to $\$ 500$ million associated with that fee render it immune to political redress. One major problemthe inanageability of loan repayment-has been alleviated, but not finally eliminated. And a problem that has been minimized-the dollar value of the loans vis-à-vis the cost of legal education - may be dormant, but will reassert itself with renewed vigor with the passage of time.

The 1986 amendments, diminished interest rates, and the LSAAP have cured several of the ills that made the GSL and SLS (incarnated as ALAS-PLUS) undesirable instruments for financing legal education. Prior to the 1986 amendments, for example, the issue of eligibility was troublesome. Throughout the 1980's the Reagan Administration consistently supported measures either to terminate all graduate and professional student eligibility for GSLs or to curtail ehgibility for students from families with adjusted gross incomes above a set figure $(\$ 32,500$ in the fiscal 1986 proposed budget). The expected family income contribution formula was also potentially subjeet to mampulation and constraints. With the expanded concept of independence in the 1986 amendments-under which all professional students are presumed financially independent provided they have not been clained as tax dependents-the tables will no longer apply for academic year 1988-89 and thereafter. Eligibility threatened the level of GSLs available to students at schools with high costs. That threat has now presumably passed and hopefully will not be revived during the next five years.

The 1986 amendments, by altering the base year for determining "expected family contribution"66 did, lowever, muddy the question of eligibility as of 1988-89 for those first-year law students who work in the year prior to their entry to law school. As independent students without dependents, the amount they will be expected to contribute to their edu-

65. Id. $\S 438(c)(2), 100$ Stat. at 1416.

66. Id. $\S 473,100$ Stat. at 1455 . 
cation will be calculated by reference to their "available taxable income"67 or their adjusted gross income for the calendar year preceding the academic year in which they apply for a loan. That income is then adjusted for income, social security, state and local taxes as well as $\$ 600$ per month maximum maintenance allowance for each month the student was not enrolled in law school before a portion up to $90 \%$ of the remainder is treated as "available income." 68

A student who took a year off between college and law school in 1987 and earned $\$ 20,000$ in California or Massachusetts (with 5\% state and local imcome tax allowances) would be deemed to have approximately $\$ 8108 \mathrm{in}$ available taxable imcome, which would be assessed at $70 \%$ (\$5676) and deducted fiom the estimated cost of attendance at law school in order to ascertain the need for a loan. 69 Such a student would have to attend a school costing at least $\$ 17,176 \mathrm{~m}$ tuition and hiving costs in order to be eligible for the full $\$ 11,500$ in GSLs and SLSs.

Of course, if the student worked in the academic year 1986-87 before entering law school in the fall of 1986, his or her 1987 calendar year earnings ${ }^{70}$ would be only $\$ 10,000$ of that $\$ 20,000$, resulting in an "expeeted family contribution" of the statutory minimum $\$ 1200,{ }^{71}$ which would not be much of a disabling factor. Because many entering law students take more than one year off prior to returning to school, however, a full calendar year's worth of past earnings would be attributed to them. Thus even with appropriate deductions and allowances, the level of loans for which they would be eligible could still be sharply limited. This constraint would be particularly true at public or low-cost private law schools.

Similarly, law students enrolled in law school would have their terni and summertime earnings as clerks at law firms comparably attributed. Those, for example, who earn in 1988 the possible feasible maximum of $\$ 10,000$ in the summer of their first year and fall of their second or as much as $\$ 20,000$ in the summer of their second year and fall of their third would be expected to contribute respectively $\$ 4339$ and $\$ 10,323$ from that income toward their education. ${ }^{72}$ The student earning $\$ 20,000$ would probably be eligible for the maximum in loans at only the most

67. Id. $\S 476(\mathrm{~b})(1)(\mathrm{A}), 100$ Stat. at 1463.

68. Id. $\S 476(\mathrm{~b})(1)(\mathrm{A})(\mathrm{i})$-(iv), (4), 100 Stat. at $1463,1464$.

69. These calculations assume the Social Security and income tax rates for 1987 set forth supra note 30.

70. The Higher Education Ameniments Act of 1986, Pub. L. No. 99-498, $\S 480$ (a), 100 Stat. 1268,1472 focuses on income "for the preceding [before the loan award year] tax year."

71. Id. $\S 476(b)(1), 100$ Stat. at 1463.

72. These calculations assume the Social Security and income tax rates for 1988 set forth supra note 30. 
expensive private law schools. The eligibility problem presented by this use of the calendar year as the crucial base for determining the student's need may well be resolved before it begins to bite in the spring of 1988 . The passage of technical amendments could return eligibility to the traditional need analysis technique of determining the student's income by reference to the estimated part-time earnings of the student during the relevant academic year. If that analysis were to apply, it is ouly the income that a student earned during law school that would be held agamst him or her. Only the students earning \$12-plus an hour during the term and $\$ 1000$-plus each week during the summer would forfeit the opportunity to take out a subsidized loan. Such students have no legitimate need for loans to pay their bills.

Of course, eligibility for a loan is worthless if no lender will make the loan. Although this problem became less difficult each year from 1980 to 1985 with respect to GSLs, it was a contmuing barrier to access to ALASs and PLUSs. Banks either had to persuade resisting students to pay interest while still in school or capitalize that interest and receive delayed repayment. Many banks were reluctant to accept either of these alternatives. Sonie lenders in sonie states refused to niake loans to resident students planning to attend schools im other states or to out-of-state students attending local schools. Sallie Mae's intervention as a direct lender of last resort eased matters, but also generated a pohtical backlash from turf-conscious state guarantee agencies. The advent of LSAAP in 1986 as a nationwide ccntral source of loans appears to have eliminated any availability questions concerning law students. ${ }^{73}$

The 1986 amendnients also changed some of the repayment terms. Law students, under the specific terns of SLS, need not repay any part of their federally subsidized loans while in law school. All SLS interest payInents can, if the lender is willing, be capitalized quarterly and added to the principal anount of the loan. ${ }^{74}$ Although that makes the SLS more palatable to students, capitalization substantially increases the sum that ultimately inust be repaid. A loan of $\$ 4000$ each year over three years at a interest rate of $9 \%$ with quarterly capitalization of interest and a sixtyday grace period prior to repayment results in a debt of $\$ 14,590-$ not $\$ 12,000$.

73. Beside helping to cure the availability problem, LSAAP provides fast and easy access to the loan programs. LSAAP has rapidly increased its percentage of the law school GSL-SLS market. This increase demonstrates how much more competitive LSAAP has become in terms of service than most banks and other guarantor-lenders.

74. Higher Education Amendments Act of 1986, Pub. L. No. 99-498, $\S 428$ A(c)(2), 100 Stat. $1268,1384$. 
The potential increase in the total amount of subsidized loans, annually and cumulatively, is one of the two most important changes produced by the 1986 amendments. In 1986 Congress increased the ceiling on subsidized loans to $\$ 11,500$ ( $\$ 7500$ in GSL and $\$ 4000$ in ALAS). ${ }^{75}$ But, with income eligibility almost rendered obsolete by the standard of independence, the ceiling is also the floor, unless the particular law school has a lower cost of attendance (all public schools in 1987-88, but no private law schools) or the student is already receiving other forms of aid that have reduced costs below $\$ 11,500$.

That boost in loan limits, accompanied by the rise in the cumulative limits of GSLs and SLSs to $\$ 54,750$ and $\$ 20,000$ respectively, ${ }^{76}$ clearly places all public law schools within the reach of apphicants and enables private school students to cover $55 \%$ of the cost of attending the most expensive school $(\$ 21,000)$ and $81 \%$ of the cost of attending the average private law school $(\$ 14,205)$. Although the loans do not cover $100 \%$ of the costs, the amount is sufficient given the fact that half of the private law schools, by definition, cost less to attend than the median figure and the fact that the more expensive schools have more scholarship money to help bridge the gap.

2. Prospects Under the 1986 Amendments. That $\$ 11,500$ in loans may be adequate today does not suggest that the overall increase in GSL and SLS limits from $\$ 8000$ in 1976 to $\$ 11,500$ in 1986 was reasonable, given the pace of inflation during the same period. From 1976 to 1986, the consumer price index nearly doubled, 77 and it rose by a factor of more than 1.3 from 1980 to 1986. If GSL and SLS loan limits kept pace with those figures in 1987, the GSL loan limit would exceed $\$ 10,000$ and the SLS loan limits would be approximately $\$ 4000$, for a total annual loan limit of $\$ 14,000-20 \%$ greater than the limits instituted by the 1986 amendments.

The failure of the GSL and SLS loan limits to keep pace with inflation has not yet interfered with access to legal education because various private loan mechanisms have developed during the past two years that offer as much as $\$ 8500$ a year in loans. The existing inflation gap of $\$ 5840$ will, however, only widen with each passing year and each inflationary increase in tuition, room, and board. For example, federally subsidized loans, if they survive untouched for sixteen years, would meet 57 to $69 \%$ of the cost of attending a public law school in 2002. Where private law schools are concerned, the $\$ 11,500$ limit will become increas-

75. Id. $\S \S 428(\mathrm{~b})(1)(\mathrm{A})(\mathrm{iii}), 428 \mathrm{~A}(\mathrm{~b})(1), 100$ Stat. at $1370,1384$.

76. Id. $\$ \S 428(\mathrm{~b})(1)(\mathrm{B})(\mathrm{ii}), 428 \mathrm{~A}(\mathrm{~b})(2), 100$ Stat. at 1370,1384 .

77 Statistical Abstract of THE UNITED States 1986, Table 795, at 477. 
ingly constrictive by 2002 , enabling a student to pay no inore than $40 \%$ of the cost of attending the least expensive private law school and only $23 \%$ of the cost of attending the most expensive private law school. If the $\$ 11,500$ limit was adjusted for a $5 \%$ average inflation rate through 2002 , it would become $\$ 25,180$, which wonld be enough to cover all public law scliool costs and between 50 and $87 \%$ of private law school costs.

The major obstacle to adjusting the loan limits has been executive branch resistance stemming from two concerns: the cost of the additional loan volume to the federal government and the manageability of repayment. Secretary Bennett raised those issues in Marcli 1985, when lie refused to act on the petition to raise GSLs to $\$ 8000 .{ }^{78} \mathrm{He}$ estimated that total loan volume for all graduate and professional students wonld morease to $\$ 480$ million in the initial year and that such a volume wonld yield a subsidy cost of $\$ 185$ million over the first five years.

The inatter of cost to the federal budget is likely to be no less acute an issue in 2002 than it is today. But with present interest rates and the 1986 law's reduction in the special allowance payable to lenders from $3.5 \%$ to $3.25 \%, 79$ the total cost to the federal government of new GSLs in a year in which ninety-one-day Treasury bills averaged no more than $5.5 \%$ would be $\$ 33.2$ million if every law student in America were to be eligible for and receive a GSL loan of $\$ 7500$. That federal outlay would underwrite $\$ 885$ million in loans, all subsidized at only $3.75 \%$ because of the 5\% origination fee. Because GSLs cover at most $40 \%$ of all law students, the cost of these loans held while in-school wonld be $\$ 31$ million in each of the second and third years at the full $8.75 \%$ subsidy. Over the course of three years, $\$ 7500$ loans each year would cost the Treasury only $\$ 159$ per person or $\$ 75$ million. This expenditure is liardly a budget-busting item. The extra $\$ 1000$ in SLSs coines cost-free to the federal government, because there would be no special allowance on a loan whose interest rate exceeded $8.75 \% .{ }^{80}$

To move these maximum loan amounts to $\$ 16,000$ for GSLs and $\$ 9000$ for SLSs as of 2002, thereby covering between a minimum of twothirds of the cost of legal education and a maximum of $100 \%$ of tuition would require only $\$ 15$ million in added costs in the initial year, ${ }^{81}$ if interest rates were to hold and only $40 \%$ of the students were to seek

78. See supra note 63 and accompanying text.

79. Higher Education Amendments Act of 1986, Pub. L. No. 99-498, $\S 428(b)(2), 100$ Stat. $1268,1374$.

80. Id.

81. Assuming that 118,000 students still attend and a variance in the rate of tuition increases of the type indicated supra at text accompanying note 20. 
loans. Paying $\$ 28$ million to leverage $\$ 1.18$ billion in loans, and thereby sustaining legal education, is an economic, if not a political, bargain.

Cost is simply not a stumbling block to more adequate federally subsidized loan levels so long as interest rates do not reach their 1980-81 level. There is no federal subsidy for SLSs at a Treasury bill rate of $5.75 \%$ or below, nor is there any federal subsidy for GSLs in the fifth year of repayment or thereafter at a Treasury bill rate of $6.75 \%$ or below. The in-school subsidy remains, assuming a 5.5\% Treasury bill rate, at $3.75 \%$ for the loan's first year and $8.75 \%$ for each in-school year thereafter, and $0.75 \%$ during the first four repayment years. These subsidies amount to $\$ 7.50$ per $\$ 1000$ of loan.

3. Debt Manageability Under the 1986 Amendments. The more substantial and legitimate objection to increased loan limits, whether those limits be raised to $\$ 11,500$ or $\$ 25,000$, stems from concern about jeopardizing students' capacity to manage debt. It is feared that a heavy debt burden may result in eitlier unbearable pressure to seek out a job in one of the highest paying large law firms, failure to save, or outright default.

This fear has some basis. Debt burdens are high and mounting. Some young and even middle-aged attorneys may well find their debt burdens impossible to handle. Debt burdens could-and the emphasis has to be on "could"- significantly affect career choices, family formation, and capital investment.

According to $1982-83$ statistics $^{82}$ compiled from GAPSFAS forms filed by law students, law students who applied for aid (well over twothirds of all students) had already accumulated a median debt of $\$ 4700$ at the time they entered law school and were leaving law school with an estimated cumulative debt of $\$ 14,700$, with the upper quartile at $\$ 18,100.83$ Other estimates of average debt upon graduation in 1983 placed it as high as $\$ 15,676.84$

The statistics on this $\$ 10$ billion-a-year industry, however, "are poor to nonexistent" and reflect a "lack of basic data to answer obvious questions about who is borrowing, how much they are borrowing, and what has happened to borrowing over time." 85 The absence of useful data is

82. Unfortunately, these statistics are the latest reliable data.

83. T. Hartle \& R. Wabnick, The Educational Indebtedness of Graduate and Professional Students 11 (Apr. 1983) (unpublished manuscript prepared for the National Commission on Student Financial Assistance).

84. See P. Butler-Nalin, A. Sanderson \& D. Redman, Financing Graduate Education 2:34 (Feb. 1983) (unpublished manuscript prepared for the Consortium on Financing Higher Education).

85. J. Hansen, Student Loans: Are They Overburdening A Generation? 6 (Dec. 1986) (unpublished research report prepared for the Joint Economic Committee of the U.S. Congress). 
likely to continue because private groups lack incentive to spend substantial sums to collect the information and because the federal budget has little room for outlays on this kind of research. The best and most recent picture of student borrowing, however, suggests that "[a]nnual and cumulative borrowing by imdividuals has grown significantly, but adjusting borrowing levels for inflation modifies the magnitude of the increase."86

Nonetheless, for those students entering law school in 1987 under the new law, the debt level outlook will be much more severe. ${ }^{87}$ Assuming that a law student borrowed as an undergraduate the full GSL amount then available $(\$ 10,000)$ as well as the full amount available over three years of law school $(\$ 22,500)$ and that the high cost of going to law school prompted the student to secure the full SLS amount $(\$ 12,000)$, the student could graduate in 1990 owing $\$ 47,090$ in federally subsidized loans. ${ }^{88}$ If the student borrowed nothing in college, the initial debt loan would still be $\$ 37,090$. NDSLs and scliool or state loans could easily raise either figure to between $\$ 50,000$ and $\$ 60,000$.

Can a beginning attorney earning $\$ 36,000$ a year readily sustain that kind of debt? The answer is "no" if the repayment period is restricted to a ten-year term. Even if the first-year lawyer obtains one of the most lucrative job offers in New York or Washington, D.C., debt repayment within a ten-year period would prove difficult. Paying back a debt of $\$ 37,090$ would require a $\$ 469.86$ payment each month (assuming an average $9 \%$ interest rate). That debt amounts to $15.5 \%$ of a gross incoine of $\$ 36,000$ and $8.7 \%$ of a gross income of $\$ 65,000$. A debt of $\$ 47,090$ would require a $\$ 609.20$ payment each month and would consume $20.3 \%$ of a gross income of $\$ 36,000$ and $11.2 \%$ of a gross incoine of $\$ 65,000$. Leading studies of debt inanageability indicate that no borrower can afford to repay educational debt in excess of $15 \%$ of pretax income (some studies suggest that $6 \%$ might be high) or $8 \%$ of posttax

86. Id. at 23.

87. Existing data support this conclusion. While the cumulative education indebtedness of the top $10 \%$ of borrowers in private law schools increased $15 \%$ (from $\$ 17,000$ in $1981-82$ to $\$ 19,500$ in 1983-84) and the top $10 \%$ of borrowers in public law schools increased $19 \%$ (from $\$ 15,000$ in 1981 82 to $\$ 17,800$ in 1983-84), the increase was far less for borrowers below those top levels. D. Horch, GAPSFAS Applicant Profiles 1981-84, at 12, 15 (Feb. 1985) (unpublished inanuscript prepared for the Educational Testing Service). Many graduates of the class of 1986 could have energed with as much as $\$ 34,000$ in debt if they used all of the GSL and ALAS/PLUS eligibility as part of LSAAP. Given the rise in debt levels for law graduates between 1981 and 1983, average debt by I986 could have reaclied $\$ 20,000$. Those students from low-income backgrounds who attend the most expensive private law schools would have been even more indebted had they obtained NDSL, state, or school loans (all of which, when taken together, anount to only one-sixth the size of the GSL program for law students).

88. The additional $\$ 2590$ derives from the quarterly capitalization of $9 \%$ interest on the SLSs until repayinent cominences 60 days after graduation. 
income. 89 A research paper prepared in 1986 by Janet Hansen for the Joint Economic Committee noted the lack of consensus on manageability. The paper indicated concern about the crude methodology used by some to define manageable indebtedness, mcluding the failure to focus on long-term implications and overall indebtedness beyond education, as well as the failure to take into account such variables as family size and the number of workers per household.90

Dwight Horch of the Educational Testing Service published a detailed study in 1984 that offered some useful guidelines.91 Horch used estimates of borrowers' projected incomes according to the job field or profession they expected to enter and applied proportions of those income streams to debt repayment. He determined that, given a repayment schedule of ten years with equal monthly installments, a law student graduating in 1988 could not readily manage a loan primcipal in excess of $\$ 10,000$-an amount from $\$ 27,000$ to $\$ 37,000$ less than the the amount borrowed by hypothetical fully loaned-out student. ${ }^{92}$

4. Tax Reform Act of 1986. In the same year that it enacted the Higher Education Amendments Act, Congress also passed another law that will have a substantial effect on debt inanageability. Until 1986, the federal government through the Internal Revenue Code had shared soine of the cost of servicing student loans by allowing the itemized deduction of personal interest expense from taxable income. ${ }^{93}$ The Tax Reform Act of 1986,94 however, abohshed the deductibility of interest on most consumer debt. ${ }^{95}$ When the class of 1990 graduates and starts to repay its loans, there will be no tax subsidy of interest payments unless the loans used to finance the education are secured by the value of an owner-occupied home. ${ }^{96}$ The Act will increase the real burden of student debt. Conversely, the Act's favorable treatinent of home loans used for education expenses will make it easier for parents-rather than students-to finance legal education. This outcome is in apparent conflict with the reality recognized by the Higher Education Amendments Act of 1986-

89. See D. Horch, Estimating Manageable Educational loan Limits for Graduate and Professional Students (1978); R. Hartman, Credit for College 14 (1971); J. Froomkin, Study of the Advantages and Disadvantages of Loans to Women (Dec. 1974) (unpublished paper prepared for the Department of Health, Education, and Welfare).

90. J. Hansen, supra note 85, at 32-33.

91. D. HoRCh, STUdent LoAN Limits: Estimated MANageable Student LoAN Limits For the Class GraduatiNg iN 1984 aNd the Class ENTER1NG 1N 1985 (1984).

92. Id. Table $\mathrm{B}$, at iii.

93. I.R.C. $\S 163$ (1982).

94. Pub. L. No. 99-514, 100 Stat. 2085.

95. Id. $\S 511(\mathrm{~b}), 100$ Stat. at 2246 (to be codified at I.R.C. $\S 163(\mathrm{~h})$ ).

96. Id. $\S 516(\mathrm{~b}), 100$ Stat. at 2247 (to be codified at I.R.C. $\S 163(\mathrm{~h})(4)$ ). 
that parents can and should bear less responsibility to finance a student's professional education.

5. Movement to Repayment Flexibility. The only solution to being overwhelmed by the prospect of repayment, other than replacing loans with nondebt financing or urging students to accept inore work in derogation of the classrooin, is to inake loan repayment terms more flexible. Congress moved in that direction in 1980 when it permitted Sallie Mae to engage in loan consolidation. ${ }^{97}$ Until the law's expiration on October 31, 1983, GSLs and NDSLs could be consolidated into a 7\% package. Payment could be extended as much as twenty years for loans totaling more than $\$ 16,000$, and options for graduated repayment were available. Thus, a borrower could have chosen either to make level payments over the course of twenty years or to start at a low level and then accelerate with increases every two years. ${ }^{98}$ The graduated option was particularly useful for students who were uncertain of their initial earning capacities or who desired to undertake some form of public service.

After a three-year hiatus, Congress revived loan consolidation in 1986. Large debts can once again be consolidated, this time at a weighted average interest, but in no event at less than $9 \% .{ }^{99}$ A twentyyear repayment term is available for consolidated loans between $\$ 20,000$ and $\$ 45,000$; a twenty-five-year repayment term is available for loans above $\$ 45,000.100$ Congress further provided that the consolidating lender sliould establisli repayment terms that would ease repayment and avoid default, including graduated or income-sensitive repayment scliedules along the lines of what Sallie Mae offered in the early 1980's. ${ }^{101}$ A minimuin payment of accrued interest, whicl would be at least $9 \%$ of the balance, ${ }^{102}$ would supersede any lower minimuin determined by graduated or income-sensitive tables.

These provisions make debt burdens manageable and permit individuals to attend expensive law schools and repay their debts witlout serious difficulty in their early professional years when their earnings are invariably lower. The new provisions, lowever well intended, may not achieve their objective. The following table covers the possibility of increased GSL-SLS borrowing limits over tine. It is based on the new consolidation rules and an assuined $9 \%$ interest rate:

97. See 20 U.S.C. $\S 1087-20$ (1982).

98. StUdENT LOAN MARKeting ASS'N, OPTIONS SElector (1981).

99. Higher Education Amendments Act of 1986, Pub. L. No. 99-498, $\S 428 \mathrm{C}(\mathrm{c})(1)(\mathrm{C}), 100$ Stat. $1268,1391$.

100. Id. $\S \S 428 \mathrm{C}(\mathrm{c})(2)(\mathrm{A})(\mathrm{iv})-(\mathrm{v}), 100$ Stat. at 1392.

101. Id. $\& 428 \mathrm{C}(\mathrm{c})(2)(\mathrm{A}), 100$ Stat. at 1392.

102. Id. $\S 428 \mathrm{C}(\mathrm{c})(3)(\mathrm{A}), 100$ Stat. at 1392. 


\begin{tabular}{|c|c|c|c|c|c|c|c|}
\hline \multirow{2}{*}{$\begin{array}{l}\text { Amount } \\
\text { Borrowed }\end{array}$} & \multirow{2}{*}{$\begin{array}{c}\text { Monthly } \\
\text { Flat }\end{array}$} & \multirow{2}{*}{$\begin{array}{c}\text { Payment } \\
\text { Graduated }\end{array}$} & \multirow{2}{*}{$\begin{array}{c}\text { Monthly } \\
\text { (yearly) } \\
\text { Salary } \\
\end{array}$} & \multicolumn{2}{|c|}{$\begin{array}{l}\text { Payment as \% } \\
\text { Salary or } \\
\text { Gross Income }\end{array}$} & \multicolumn{2}{|c|}{$\begin{array}{l}\text { Payment as } \\
\text { \% Disposable } \\
\text { Income }\end{array}$} \\
\hline & & & & Flat & Grad. & Flat & Grad. \\
\hline \multirow[t]{5}{*}{$\$ 20,000$} & 179.95 & 150.00 & $(25,000)$ & 8.64 & 7.20 & 11.52 & 9.60 \\
\hline & & & $(35,000)$ & 6.17 & 5.14 & 8.71 & 7.26 \\
\hline & & & $(40,000)$ & 5.40 & 4.50 & 7.77 & 6.48 \\
\hline & & & $(50,000)$ & 4.32 & 3.60 & 6.42 & 5.35 \\
\hline & & & $(65,000)$ & 3.32 & 2.77 & 5.03 & 4.19 \\
\hline \multirow[t]{5}{*}{$\$ 30,000$} & 269.92 & 225.00 & $(25,000)$ & 12.96 & 10.80 & 17.28 & 14.40 \\
\hline & & & $(35,000)$ & 9.25 & 7.71 & 13.06 & 10.89 \\
\hline & & & $(40,000)$ & 8.11 & 6.75 & 11.66 & 9.72 \\
\hline & & & $(50,000)$ & 6.48 & 5.40 & 9.63 & 8.03 \\
\hline & & & $(65,000)$ & 4.98 & 4.15 & 7.55 & 6.29 \\
\hline \multirow[t]{5}{*}{$\$ 37,090$} & 333.71 & 278.17 & $(25,000)$ & 16.02 & 13.35 & 21.36 & 17.81 \\
\hline & & & $(35,000)$ & 11.41 & 9.54 & 16.15 & 13.46 \\
\hline & & & $(40,000)$ & 10.02 & 8.35 & 14.45 & 12.02 \\
\hline & & & $(50,000)$ & 8.01 & 6.68 & 11.91 & 9.93 \\
\hline & & & $(65,000)$ & 6.16 & 5.14 & 9.33 & 7.78 \\
\hline \multirow[t]{5}{*}{$\$ 50,000$} & 419.60 & 375.00 & $(25,000)$ & 20.14 & 18.00 & 26.86 & 24.01 \\
\hline & & & $(35,000)$ & 14.38 & 12.86 & 20.31 & 18.15 \\
\hline & & & $(40,000)$ & 12.59 & 11.25 & 18.13 & 16.20 \\
\hline & & & $(50,000)$ & 10.07 & 9.00 & 14.98 & 13.38 \\
\hline & & & $(65,000)$ & 7.75 & 6.92 & 11.73 & 10.48 \\
\hline \multirow[t]{5}{*}{$\$ 60,000$} & 503.52 & 450.00 & $(25,000)$ & 24.17 & 21.60 & 32.24 & 28.80 \\
\hline & & & $(35,000)$ & 17.26 & 15.42 & 24.37 & 21.78 \\
\hline & & & $(40,000)$ & 15.11 & 13.50 & 21.75 & 19.44 \\
\hline & & & $(50,000)$ & 12.08 & 10.80 & 17.97 & 16.06 \\
\hline & & & $(65,000)$ & 9.30 & 8.31 & 14.08 & 13.59 \\
\hline
\end{tabular}

The table shows that, at the maximum debt level for law students entering law school in 1987 (approximately $\$ 50,000$ ), a graduate earning at or slightly above the projected median starting salary for the student's year of graduation ( $\$ 43,800$ in 1990) would have to make debt repayments amounting to 15 to $16 \%$ of disposable income and shightly above $10 \%$ of gross income. A single student earning $\$ 43,800$ would have approximately $\$ 2500$ a month left after taxes prior to making the debt repayment. With educational debts deducted, either $\$ 2080.40$ or $\$ 2125$ would remain. Though not an uncomfortable amount of after-tax discretionary income, it would hardly permit a high living style in major urban areas. The more important point is that the amount of after-tax discretionary income would seriously shrink should the starting salary be less than the expected median, which by definition would be the case for onehalf of the students. 
6. Effects of Debt on Students and Lawyers. No chance exists that the cost of legal education will diminish or that tuition will be lowered. Costs may inoderate in the pace of their increase, but that is the most that can be expected. There are only a few possible ways out of this bind. First, law school apphicants could choose to go to public or the less expensive private schools, thereby reducing the tuition-related portion of their borrowing and keeping their loans well below the federal maximum. That choice might result in their obtaining a job that pays less. In terms of debt manageability, however, borrowing only $\$ 20,000$ and earning ouly $\$ 25,000$ may be preferable to borrowing $\$ 60,000$ and making $\$ 65,000$. Second, law students could reduce borrowing by relying inore heavily on their parents, applying for larger grants-in-aid from the schools (which, if awarded, automatically inflate the amounts that others will need to borrow), or stepping up their in-school and vacation-time work effort (which may entail a significant cost to their legal education).

This bind becomes even more acute when projected into 2000-03. Student borrowing would have to climb to at least $\$ 66,000$ to cover the $73 \%$ of average private law school attendance costs (at the low predicted rate of inflation in tuition) now covered by the $\$ 11,500$ annual loan limit. The $\$ 66,000$ amount is not currently available from federal loan programs, nor would that level of debt fall within the current range of affordability unless an individual's starting salary is $\$ 65,000$. Because a starting salary of $\$ 36,000$ in 1982 will become $\$ 82,500$ in 2003 , assuming a 5\% annual increase, a $\$ 66,000$ debt might be barely affordable. Agam it must be borne in mind that half of the graduates will be earning less than $\$ 66,000$.

Two other factors require mention. Exercising the consolidation option and stretching out repayment for twenty-five years exacts a hidden penalty. What was a $\$ 50,000$ debt in a lump sum is $\$ 72,800$ over ten years and becomes $\$ 125,800$ when repaid over twenty-five years-2.5 times larger than its original size. If repayed at a $10 \%$ interest rate, it would grow to $\$ 136,300$ or 2.7 times larger.

Because of the effect of inflation, however, the total amount of dollars exacted by the penalty may overstate the actual burden on the graduate. If two-thirds of the debt's repayment could be postponed until the last ten years of the twenty-five year period, and inflation averaged 5\% annually, dollars repaid at the end of the period would have a real value of about thirty cents in current dollars, and dollars repaid after fifteen years would have a value of less than forty-five cents. Time would be responsible for paying back over $50 \%$ of the entire debt, almost paralleling the increase in the debt brought about by extended repayment. 
Whether or not debt levels are manageable, repayment itself may substantially affect the lifestyles and choices of graduates, with adverse effects reflected, in turn, in the numbers and quality of future law school applicants. Proof of the existence and severity of these effects is hard to come by and is, at best, highly anecdotal. Studies collected and reviewed for the Joint Economic Comnittee in December 1986 suggest that there is little evidence that (1) the ability of debtors to borrow in the future for other consumption lias been compromised, (2) debtors have been deterred froin marrying, (3) debtors feel compelled to take the highest-paying jobs available, or (4) there is any relationship between the shift in student aid policy to heavier use of loans and the decline in enrollment of minorities or women.103 For example, lenders do not appear to bar young adults with educational debts from obtaining home or car loans. ${ }^{104}$ Researcliers believe that neither the decision to marry and start a family nor the choice of job is at the mercy of the level of educational debt. ${ }^{105} \mathrm{~A}$ survey of the class of 1984 at thirty elite undergraduate schools showed "no evidence of any relationship between undergraduate indebtedness and postgraduation plans." 106 Finally, although the earnings of blacks and woinen are lower than those of white males of similar educational backgrounds, that differential apparently does not persuade women and minorities not to borrow when loans are the only resource available to finance education. ${ }^{107}$

All of the studies, however, apply primarily to undergraduates-not law students, many of whom have far heavier debt burdens. What effect heavy student debt has on law school student demographics-which may depend on low good a deal legal education appears compared to alternatives-and on borrowers after graduation remains an open question.

\section{Other Sources of Support.}

1. The Law Schools. All education is subsidized to some extent by the institutions that provide it. In law schools, subsidies come either by way of endowment earnings, or by annual gifts, or by way of a scheme of internal redistribution of wealth whereby as much as 10 to $15 \%$ of tuition becomes scholarship aid. In 1985-86, those grant/scholarship resources amounted to only $\$ 74.2$ milhon, ${ }^{108}$ an increase of only $8.7 \%$ over

103. J. Hansen, supra note 85 , at 29-30, 43-44, 57 .

104. Id. at $28,34,44$. Outstanding GSL-PLUS debt amounts to $\$ 46$ billion or slightly over $1.4 \%$ of all individual debt and $6 \%$ of outstanding consumer credit.

105. Id. at $35-36,44$.

106. Id. at 52,61 .

107. Id. at $49,53,57$.

108. K. Grove, supra note 17 , at Table J-2. 
the prior year. Scholarships paid for only $11.7 \%$ of all tuitions and fees and were primarily derived (55\%) from tuition rebates or in-house welfare, which are directly translated into tuition increases applicable to all students, with endowments accounting for only $23 \%$ of the total. ${ }^{109}$

Although scholarships ease the financial strain for some students, the relief is in fact relatively minor. The average dollar level of scholarships is $\$ 2500$, while costs range from $\$ 9000$ to $\$ 20,000$. Furthermore, only $26 \%$ of all students receive scholarships. ${ }^{110}$ The inadequacy of scholarships as a source of funding will continue, particularly if the rate of increase in fellowships continues to lag behind the rate of increase in tuition. Although $46.7 \%$ of student aid at the undergraduate level in 1985-86 took the form of grants (down from 55.5\% in 1980-81), ${ }^{111}$ no significant grant programs for law students are funded by the federal government or the states. CLEO and GPOP, for exainple, together offer less than $\$ 2$ million in aid to law students. ${ }^{112}$ As a result, grants available to law students cover less than $5 \%$ of the outlays required for law school attendance. Even less federal assistance in the form of grants may become available in the future because of the direct impact of grants on the budget.

Some law schools liave loan programs of their own (amounting to $\$ 12.6$ million in $1985-86,113$ down from $\$ 16.1$ million in 1984-8514) which are likely to decline after federal loan expansion. Many offer students paying jobs, which amount to $\$ 9$ million. ${ }^{115}$

2. The States. The states heavily contribute to legal education through appropriations for public law scliools. The $\$ 6151$ differential between the average public law school tuition and the average private law scliool tuition in 1986-87 is the result of state subsidies. The cost of attending law school for all enrollees would rise as inuch as $\$ 275$ million

109. Id.

110. $I d$.

111. The COLlege BOARD, supra note 59 , at 8.

112. The CLEO appropriation is $\$ 1.5$ million, at least $25 \%$ of which is used for administration. Law students have historically obtained slightly under 10\% of GPOP funding, now at $\$ 11.8$ million. See Higher Education Amendments Act of 1986, Pub. L. No. 99-498, $\S \S 921-923,100$ Stat. 1268, 1550-52.

113. K. Grove, Overview of Loans Funds Other than FGSL's at 164 ABA-Approved Law Schools, Table J-4 (Mar. 24, 1986) (Consultant's Memorandum QS8586-28 to the Deans of ABAApproved Law Schools).

114. J. White, Overview of Loan Funds Other than FGSL's at 168 ABA-Approved Law Schools, Table J-4 (Mar. 15, 1985) (Consultant's Memorandum QS8485-20 to the Deans of ABAApproved Law Schools).

115. K. Grove, Overview of Work-Study and Student Employment Funds at 158 ABA-Approved Law Schools, Table J-3 (Mar. 21, 1986) (Consultant's Memorandum QS8586-27 to the Deans of ABA-Approved Law Schools). 
if the state support were removed. This support, of course, is selectiveonly students attending public law schools benefit.

States do fund modest loan programs, but these programs will become increasingly more modest as the federal income-tax cap on the issuance of tax-exempt bonds to underwrite student loans begins to bite. The level of state loans in $1985-86$ was $\$ 20.8$ million, only shightly over $1 \%$ of the price tag on legal education. ${ }^{116}$

3. Private Funding. The combined federal loan limits for law students do not represent the actual limit on what students can borrow. Students can obtain substantial additional loan money with reasonable interest rates and repayment terms from private sources. Unfortunately, however, such borrowing only compounds the debt manageability problem.

The Law Access Loan (LAL) offered through LSAC enables a student to borrow $\$ 10,000$ a year. ${ }^{117}$ The LAL requires the student borrower to pay a floating interest rate of approximately $9 \%$ today (ninetyone-day Treasury bills plus 3.5\%) to be repaid over fifteen years, with interest payments capitalizable during the years the student is in school. ${ }^{118}$ This rate is basically a 2.5 multiple of SLS with a shorter repayment period (given SLS's consolidation option) and thus a $21 \%$ heavier repayment burden $(\$ 30,000$ at $9 \%$ over fiftecn years is serviced by $\$ 304.28$ monthly as opposed to $\$ 251.76$ monthly over twenty-five years). This heavier burden is compounded by relatively stiff imsurance premiums, particularly if interest is capitalized and there is no cosigner, which means that the loan's effective yield could be reduced by as much as $10.25 \% .119$ This aspect makes the LAL shightly less favorable than the GSL or SLS. One distinguishing helpful feature is that debt repayment is eased in the early stages of practice by a mine-month grace period (as opposed to either six months or sixty days) ${ }^{120}$ and the option to pay $m$ terest only for the first three years thereafter (as might be the case for consolidated GSLs and SLSs on a graduated repayment schedule at the minimum). 121

Both Sallie Mae and Chase Manhattan Bank are similar sources for private borrowing. Sallie Mae's GradEd Financing Plan offers law students between $\$ 1500$ and $\$ 7500$ each year on top of federal loans, with a

116. K. Grove, supra note 113.

117. LAW ACCESS NEWSL., June, 1986, at 4.

118. $I d$.

119. A 9.75\% insurance premium is deducted for a loan with deferred interest and no cosigner and a $0.5 \%$ origination fee is charged. $I d$.

120. $I d$.

121. Id. 
ceiling of $\$ 15,000$ in GradEd loans and $\$ 45,000$ in education borrowing overall. ${ }^{122}$ Full use of GSL and SLS, therefore, would preclude eligibility for GradEd loans. Interest is identical to LAL, and there is a $6 \%$ origination fee. ${ }^{123}$ Interest during school can be accrued and capitalized. The repayment period can be as long as fiftecn years. ${ }^{124}$ Chase Extra is coinparable to GradEd, with an annual maximum of $\$ 10,000$, an overall maximum of $\$ 50,000$, at an interest rate one-half of a percentage point lower, and an origination fee one percentage point lower. ${ }^{125}$

4. Employers. The most accordion-like resource for financing legal education other than nonmandatory parental contributions is student earnings. As indicated above, ${ }^{126}$ current earning possibilities over the three years of law school range from $\$ 17,100$ to $\$ 31,100$. Even after deducting social security taxes, income taxes, and of summer hiving expenses, work can yield a sum that is two-thirds as large as the proceeds fron loans. The work opportunities offered by the law schools themselves (\$13.6 million in work-study in 1985-86, including the law school match of the federal monies, and $\$ 12$ million in law school employnient separate and apart from work-study ${ }^{127}$ ), however, are carefully monitored to avoid interference with the learning process. Law firm hours, on the other hand, are not monitored and compete with the classroom, ABA rules or no ABA rules. ${ }^{128}$ The incentives for those of the 98,000 full-time students who can become law firm clerks to do so are obvious.

The rcal contributions of law firms to legal education sten from the salaries they pay law students. The prospect of highly paid law firm work is what attracts many applicants to law school in the first place. Furthermore, high salaries ultimately make tuition payment possible. Law firms can do more to make law school affordable by hiring students than by giving relatively insubstantial donations directly to the school. A firm that donates $\$ 10,000$ a year to a law school to support a scholarship in the firm's name will have some slight effect in reducing tuition costs for one student. But the altruistic benefit of that gift does not compare with the benefits that both the students and a firm receive when a firm employs a number of law student clerks.

122. Student Loan Marketing Ass'N, GradEdFinancing Loan Application Krt 2 (1985).

123. Id. at 3.

124. Id.

125. LSAS, Comparison and ReView of Alternative LoAN Programs 1 (1986).

126. See supra note 31 and accompanying text.

127. K. Grove, supra note 115 , Table J3.

128. See Standards for Approval of Law Schools I-305(a)(iii) (1985). 


\section{Do Solutions Exist?}

Increasing tuition and increasing living expenses force law students to borrow more and work during scliool. No sooner do salaries increase than tuitions outstrip that increase. Thus inore students borrow even more and the newly inflated salaries becoine even inore heavily burdened with debt repayment. These difficulties inay pose soine threat to crucial life clioices and soine deterrence to those who have the most to fear from high debt loads.

The federal loan programs have been altered and expanded to lielp ease the cycle that law students face. Payment for higher education has been turned upside down, with children retroactively responsible for financing their own professional degrees from the higher earning power attributable to those degrees. Yet financial stress has only been shifted from one generation to the next. The result is that current and future generations have to confront and overcoine debt loads.

Is there anything else that the federal government or private institutions can do to alleviate or reinedy the matter? One suggestion has been to offer incoine-contingent loans. ${ }^{129}$ Under this scheine, loan payments would be set at a manageable percentage of income. This variability would presunnably permit graduates greater flexibility in making career choices.

Although the theory is excellent, the impleinentation proposals are flawed. Alinost all of the "income contingent" proposals fail to resolve the politically explosive issue of the source of the initial capital. Boston University President John Silber's Tuition Advance Fund (TAF) concept envisions a fund from which students could draw advances to be repaid after graduation through payroll deductions tailored to income. A TAF sufficient to finance 118,000 law school enrollees could consume as much as $10 \%$ of the entire federal budget each year until repayment began. That repayment inight eventually result in a self-perpetuating revolving fund does not resolve the interim capital problem. The same criticisin may be leveled against other variants, such as Catholic University President William J. Byron's idea for creating a revolving fund from which students could borrow subject to paycheck deductions by the Internal Revenue Service. Father Byron would service the initial fund from waste in the Pentagon budget. Congressman Thoinas Petri's proposal, IncomeDependent Education Assistance (IDEA) ${ }^{130}$ involves a similar scheme, but would obtain the initial capital froin federally guaranteed bonds sold

129. Werner, Loan Cost Shift to Students is Sought, N.Y. Times, Jan. 2, 1987, at A14, col. 4.

130. Petri's concept is the only one that has been translated into precise legislative language. See H.R, 2733, 99th Cong., 1st Sess. (1986). 
by guarantee agencies. ${ }^{131}$

Secretary Bennett is the latest to come forward with a plan. His Income Contingent Loan (ICL) program contemplates repayment determined as a percentage of the borrower's adjusted gross income. The ICL program received a pilot $\$ 5$ million financing in the Higher Education Amendments Act of 1986.132 Secretary Bennett has never specified where the initial funding for a nationwide ICL program will come from: borrowers are to pay nothing until nine months after graduation and not much more for another two years thereafter. The Administration's proposed outlay of $\$ 600$ million for fiscal year 1988 would provide only 500,000 loans and would be funded at the expense of other federal educational aid programs. ${ }^{133}$

Money is not a minor techıricality. Even if TAF or IDEA or ICL were to move from the drafting board to the statute book, none would sufficiently highten debt loads at the professional education level in any meaningful way. First, none of these programs offers sufficient initial loan maxima. The ICL program would allow $\$ 17,500$ in all; ${ }^{134}$ ICL would allow $\$ 50,000$, with $\$ 32,500$ for graduate education; ${ }^{135}$ and IDEA would allow $\$ 40,000$ less any amounts borrowed under other federal programs. ${ }^{136}$ Even those amounts, furthermore, are to be repaid according to income tables that ensure that no borrower owes more than $15 \%$ of adjusted gross income in repayments in any given year. But, at the maximum level of borrowing, $15 \%$ is not only the ceiling, but also the floor. Fifteen percent of gross is not particularly reasonable when compared with the perccntages possible under current programs. ${ }^{137}$ Effective rehef would exist only for those lawyers who either accept jobs that are well below public sector medians or fail to find jobs at all.

IDEA and its variations are programs whose time has not and should not come. Because none of the programs is better than GSL and SLS in making debt manageable and because their loan limits are lower, they would only diminish the benefits flowing from current programs. Furthermore, Congress has already acted on some of the ideas contained in the proposed programs. The 1986 consolidation amendments extend

131. Petri recognizes the need for appropriations in the first years prior to repayment to pay interest on the bonds if they are not zero coupon.

132. Higher Education Amendments Act of 1986, Pub. L. No. 99-498, $\$ \S 451-455,100$ Stat. $1268,1437-39$.

133. Werner, supra note 129.

134. Higher Education Amendments Act of 1986, Pub. L. No. 99-498, § 454(a)(2), 100 Stat. $1268,1439$.

135. Werner, supra note 129.

136. H.R. 2733, supra note $130, \S 103(\mathrm{a})(2)$.

137. See table supra p. 254. 
repayment on the largest loans to twenty-five years ${ }^{138}$ contain reasonable deferment provisions, ${ }^{139}$ and provide for the possibility of graduated repayments. ${ }^{140}$

No more can be expected. Meaningful federal grants for law students are highly unlikely, and the only other nonloan source of aid that can be readily affected by the government is work. The possibility of government payment of law school tuition im exchange for certain number of years of national service runs afoul of the budget outlay problem. The United States could mandate the service, but could not pay for it. In any event, law students are already mdentured servants of the law firms that effectively pay their tuitions.

Forgiveness of loans based on good work in the public sector or public interest activity was proposed by law schools and rejected by Congress in 1979. A number of law schools, realizing that the federal government will not act, have taken the initiative to shape and inplement relatively modest private programs. ${ }^{141}$ Under such programs, a qualifying graduate either receives an imterest-free loan from the school to pay off some portion of existing federal loans, a small stipend (e.g., \$2000), or a deferral of loans owed to the school. Over time, some of the new and old debt will be forgiven. In order to be eligible, a graduate must (1) earn below a specified sum (usually either $\$ 25,000, \$ 30,000$, or the lowest salary payable to a federal attorney, currently shightly over $\$ 26,000$ ), often including adjusted earnings of a spouse, by (2) working either for public (federal, state, or local) employers or institutional employers that are tax exempt under section 501(c)(3) of the Internal Revenue Code. Graduates in clerkship posts are often excluded. These programs are modest in funding and apparently have not been widely used to date. Assuming that all schools participated, that the average debt upon graduation was $\$ 40,000$, and that $10 \%$ of all graduates sought public interest jobs, $\$ 14.5$ million a year would be needed to support this kind of program alone and that $\$ 14.5$ million would be plowed back into tuition.

\section{CONCLUSION}

The prospects for solving of the problems of financing legal education by a deus ex machina are as dim as the prospects for solving those

138. Higher Education Amendments Act of 1986, Pub. L. No. 99-498, §428C(c)(2)(A)(v), 100 Stat. $1268,1392$.

139. Id. $\S 428 \mathrm{C}(b)(4)(C), 100$ Stat. at 1391.

140. Id. $\S 428 \mathrm{C}(\mathrm{c})(2)$.

141. Forgiveness or loan repayment assistance programs have been instituted by Columbia, Cornell, Georgetown, Harvard, NYU, Northwestern, Stanford, University of Virginia, and Yale. 
problems through programs generated by the law schools. Band-aids carefully applied may be the only available response.

Minorities will either have to be given the lion's share of available scholarships or convinced that heavy debt is not harmful to their health, which may require considerable advocacy given evidence of their lack of success to partnerships in large firms. Low- or moderate-income nonminorities will also have their debt fears assuaged, although employment opporturities may be more readily available to them. Upper-middle class and wealthy students can continue to rely on their parents and the prospect of higher earnings flowing from their attendance at the more experive private schools to cover any borrowing.

At the margin, federal loan consolidation and graduated repayment schemes and private forgiveness may enable interested students to spend a few years in the public and nonprofit sectors. No program now in existence can compete with or offset the lure of in-school work dollars in the second and third years of law school. The drive to become a corporate attorney in a large firm in order to relieve debt burdens may capture even more graduates, further accelerating the trend to concentration in the profession. Substantial debt burdens may prompt attorneys to postpone forming families or making large capital investments.

Law school will likely remam affordable in 2000 or 2003 in the sense that 118,000 selected individuals will be able to meet the bills when due with parental or federal checks, school credits, or banked earnings. Nevertheless, we have good reason to worry about the quality of legal education, the composition of the profession, and the lifestyles and goals of attorneys. 